\title{
Barbara Michalczyk
}

\section{Warszawskie teatry Stanisławy Wysockiej}

Stanisława Wysocka w momencie odzyskania przez Polskę niepodległości miała czterdzieści jeden lat. Była dojrzałą i świadomą artystką, która zdążyła zmierzyć się $\mathrm{z}$ różnymi rolami: aktorki, dyrektorki teatru, reżyserki oraz pedagożki teatralnej. Już w 1920 jej nazwisko pojawiało się - obok Wyspiańskiego, Osterwy czy Szyfmana na liście reformatorów teatru w Polsce'. Dyrektorskie, reżyserskie i pedagogiczne doświadczenia Wysockiej ukształtowały jej poglądy na teatr, którym szczególnie intensywnie dawała wyraz w pierwszej połowie lat dwudziestych, równolegle do prowadzonej wówczas działalności pedagogicznej oraz prób odtworzenia Teatru Studya w Warszawie.

\footnotetext{
1 Antonina Sokolicz (?), , Stary a nowy teatr", w: Myśl teatralna polskiej awangardy 1918-1939: antologia, wybór i wstęp Stanisław Marczak-Oborski (Warszawa: Wydawnictwa Artystyczne i Filmowe, 1973), 303.
} 
Przedmiotem analizy podjętej w artykule będą powiązania między poglądami teatralnymi Wysockiej a jej pracą pedagogiczną i działalnością scen, które w tym okresie organizowała - Teatru w Pomarańczarni (lipiec-sierpień 1920) oraz Teatru Rybałt (grudzień 1925-czerwiec 1926). W badaniach Zbigniewa Wilskiego, monografisty artystki, oba teatry potraktowane zostały marginalnie². Tymczasem dostrzeżenie zależności pomiędzy teoretycznymi założeniami a trudnościami, przed jakimi stanęła Wysocka przy ich realizacji, pozwala przesunąć akcenty w ocenie jej dorobku, docenić wielotorowość jej zaangażowania w tworzenie nowego teatru w dwudziestoleciu międzywojennym. Zaproponowana $w$ artykule krytyczno-porównawcza lektura tekstów źródłowych - listów, wspomnień i artykułów Wysockiej - ma odsłonić rozmaite aspekty relacji między teorią a praktyką.

\section{Kijowski Teatr Studya}

W rozwoju myślenia Wysockiej o teatrze kluczową rolę odegrał Teatr Studya ${ }^{3}$. Nazwa nieprzypadkowo sugeruje związki z moskiewskim I Studiem Konstantina Stanisławskiego. To właśnie efekty sceniczne pracy Studia, w przeciwieństwie do naturalistycznych przedstawień MChT-u, wzbudziły zachwyt aktorki w czasie jej pobytu w Moskwie w lutym 19154. Chociaż znajomość ze Stanisławskim podtrzymywała głównie listownie, to właśnie dzięki zachętom z jego strony była gotowa realizować kolejne śmiałe plany. Wprawdzie nie zgadzali się w wielu kwestiach, na przykład w ocenie naturalizmu, który zdaniem Wysockiej odpowiadał za kryzys trawiący teatr, jednak Stanisławski nazywał ją swoją uczennicą, a ona jako pierwsza wdrażała w Polsce rozwiązania wypracowane w jego teatrach ${ }^{5}$.

Wysocka zaczęła pracę dydaktyczną w Kijowie w marcu 1915 od popularnych wśród młodzieży zajęć z dykcji i deklamacji ${ }^{6}$. W związku z aspiracjami adeptów latem 1916 jej studio aktorskie przerodziło się w regularny teatr. W Teatrze Kameralnym trzon zespołu stanowiła grupa zawodowych aktorów, dyrektorka nie zrezygnowała jednak z kształcenia młodych artystów. Uważała, że aktorzy muszą uczyć się w kontakcie ze sceną, dlatego obsadzała młodzież w rolach epizodycznych.

\footnotetext{
2 Opisowi Teatru Rybałt Wilski poświęcił niecałą stronę, a Teatr w Pomarańczarni zostałjedynie wymieniony w kalendarium życia aktorki. Zob. Zbigniew Wilski, Wielka tragiczka (Kraków: Wydawnictwo Literackie, 1982), 57-58 i 274.

3 Historia działalności Teatru Studya została przedstawiona przez Horbatowskiego i Wilskiego, znana jest także ze wspomnień Iwaszkiewicza. Zob.: Piotr Horbatowski, Polskie życie teatralne w Kijowie w latach 1905-1918 (Kraków: Wydawnictwo Uniwersytetu Jagiellońskiego, 2009); Jarosław Iwaszkiewicz, Stanisława Wysocka i jej kijowski teatr „Studya": wspomnienie (Wydawnictwa Artystyczne i Filmowe, 1963); Wilski, Wielka tragiczka, 41-51.

4 Zobaczyła wówczas m.in. Świerszcza za kominem Dickensa, co mogło wpłynąć na wybór właśnie tego dramatu do pracy z młodzieżą w Kijowie. Zob. Stanisława Wysocka, Teatr przyszłości, oprac. Zbigniew Wilski (Warszawa: Wydawnictwa Artystyczne i Filmowe, 1973), 199-200.

5 Zob.: Iwaszkiewicz, Wysocka i kijowski teatr "Studya", 22; Irena Schiller, Stanisławski a teatr polski (Warszawa: Państwowy Instytut Wydawniczy, 1965), 190-195; Wilski, Wielka tragiczka, 80-81.

6 Horbatowski, Polskie życie teatralne w Kijowie, 162-180.
} 
Na tym jednak nie kończyły się zadania „studyowców”: wspólnie wykonywali dekoracje, szyli kostiumy, a także obsługiwali widownię i bufet. Wydaje się, że dyrektorka chciała zaszczepić im szacunek dla pracowników teatru i uświadomić, jakiego wysiłku wymaga jego prowadzenie. Nie bała się także eksperymentów artystycznych, na przykład prób redefiniowana przestrzeni teatralnej poprzez wprowadzanie aktorów między widzów. Jako pierwsza w polskim teatrze zrezygnowała z rampy i budki suflera, a także z oklasków7. Jej innowacyjny teatr zyskał aprobatę publiczności oraz krytyki, choć niewykluczone, że zawdzięczał ją zawieszeniu pewnych oczekiwań i przyzwyczajeń na czas wojny.

Podstawowym celem kijowskiego projektu Wysockiej było stworzenie podwalin pod nowoczesny teatr narodowy, który można by kontynuować w niepodległej Polsce. Tymczasem zarzucano jej, że kopiuje rosyjskie rozwiązania, a więc brak w jej przedsięwzięciu pierwiastka narodowego. Kwitowała to złośliwie, podkreślając, że teatr w Polsce nie ma żadnej formy, jest jedynie nieudolną próbą powielania niemieckich i francuskich wzorców. Budzenie ducha w polskim teatrze w miejsce panującego w nim szablonu było według niej najpilniejszą misją ${ }^{8}$.

\section{Reformatorka}

W odrodzonej Polsce Wysocka nie od razu mogła przystąpić do tworzenia swojej sceny. W grudniu 1919 snuła plany wyjazdu do Warszawy, by - jak zdradziła reporterowi "Gońca Krakowskiego"9 - tam otworzyć teatr, do czego nie doszło z nieznanych do końca przyczyn. W pierwszej połowie 1920 łączyła więc występy gościnne w Krakowie i Łodzi z działalnością publicystyczną. Opublikowała w tym roku pięć artykułów10, w których wyłuszczyła podstawy swojego myślenia o teatrze i jego kondycji. W późniejszych tekstach pojawiały się w zasadzie tylko uzupełnienia pomysłów z tego wczesnego okresu. Nigdy nie uważała się za reformatorkę. W pracach teoretycznych skupiała się na aspektach związanych z praktyką sceniczną oraz funkcjonowaniem teatru, ale nie proponowała konkretnych rozwiązań. Wzywała jedynie do odnowienia teatru: teatr przyszłości miał być pełnym harmonii tworem plastycznym, rytmicznym i muzycznym, realizującym idee Wyspiańskiego, tak jak je pojmowała".

\footnotetext{
7 Horbatowski, 178-179.

8 Wysocka, Teatr przyszłości, 53-56.

9 Zob. Sm., ,Stanisława Wysocka", Goniec Krakowski, nr 343 (1919):2-3, https://jbc.bj.uj.edu.pl/dlibra/publication/59246/ edition/53225/content

${ }^{10}$ Chodzi tu o teksty: „Tylko aktor”, Życie Teatru, nr 1 (1920); „Refleksje”, Życie Teatru, nr 2 (1920); „Reżyser a krytyk”, Nowy Przegląd Literatury i Sztuki, nr 3 (1920); „Do niezadowolonych”, Scena Polska, nr 2 (1920); „Na zgubnej drodze”, Rzeczpospolita, nr 167 (1920). Wszystkie cytowane są za: Wysocka, Teatr przyszłości.

11 Wysocka, Teatr przyszłości, 55.
} 
Pisma teatralne aktorki nie stanowią precyzyjnie skonstruowanej całości, nie były bowiem planowane jako zwarta publikacja, zostały zebrane dopiero przez jej biografa, Zbigniewa Wilskiego, w tomie Teatr przyszłości. Wiele myśli się w nich powtarza, niektóre zmieniają znaczenie, jak choćby definicja podstawy teatru zależnie od kontekstu może być nią aktor, synteza, harmonia lub wizyjność. Nie brak tu także pojęć nieprecyzyjnych, na przykład duch może odnosić się do utworu lub autora - wówczas Wysocka pisze o duchu Sło wackiego czy du chu Wyspiańskiego, niekiedy zaś jest definiowany w kontekście narodowym, jako suma tego, co wszyscy wniosą do tworzonego na nowo polskiego teatru.

Charakterystyczne dla myśli teatralnej Wysockiej jest przede wszystkim konsekwentne wskazywanie na naturalizm jako przyczynę kryzysu artystycznego. „Teatr jest teatrem, a nie kopiowaniem życia”, podkreślała ${ }^{22}$. Ten prąd według niej prowadzi do wyjałowienia - z jednej strony aktora, który przestaje twórczo pracować, z drugiej zaś widza, który nudzi się i nie współtworzy widowiska. Naturalizm to dla Wysockiej synonim teatru współczesnego, złośliwie nazywanego życiolizm em. W praktyce scenicznej zaś powiązany jest z int u icją, czyli improwizacją, która zastępuje ciężką pracę. W koncepcji Wysockiej tak rozumianej intuicji zostaje przeciwstawiony in telekt ualizm oraz te atr in telektualny: „Teatr odrodzony [...] będzie bez wątpienia teatrem intelektualnym, w przeciwieństwie do dzisiejszego intuicyjnego"'3. Nie chodzi jej o teatr formy, którą z zasady uznaje za zimną, ani o erudycyjny teatr dla elity, zwłaszcza że bardzo intensywnie postulowała inkluzywność. Intelektualizm w tym wypadku oznacza więc aktorską metodę pracy nad rolą - drobiazgowe studium duszy (czyli życia wewnętrznego) oraz ciała odgrywanej postaci. Jeśli przyjmie się takie rozróżnienie intelektualizmu i naturalizmu, trudno się dziwić, że Wysocka nie zgadzała się na łatkę aktorki naturalistycznej.

W centrum proponowanych zmian jest aktor - według Wysockiej bowiem teatru nie może odmienić nikt inny'14. Aktor u Wysockiej, podobnie jak u Osterwy, jest kapłanem sztuki, każde z nich rozumie jednak kapłaństwo inaczej. Aktor Wysockiej powinien poświęcić się sztuce, ale sam spektakl nie stanowi misterium dla wtajemniczonych, a widzowie powinni wyczuwać w aktorach radość tworzenia ${ }^{15}$. W jej rozumowaniu praca aktorska jest procesem twórczym, w którym musi wziąć udział także widz, by na nowo zacząć myśleć i używać wyobraźni. Osterwa nie podzielał jej przekonania, że tylko aktor może odnowić teatr. Wprawdzie on także

\footnotetext{
12 Wysocka, 38. Krytyka naturalizmu pojawia się w mniejszym lub większym stopniu we wszystkich analizowanych tekstach.

13 Wysocka, 38.

14 Wysocka, 55-56.

15 To pojęcie nie zostało w pełni rozwinięte przez Wysocką, wydaje się jednak bliskie kategorii radości twórczej z Sensu twórczości Nikołaja Bierdiajewa, wydanej po raz pierwszy w 1915. Filozof rozumie radość twórczą po prostu jako radość tworzenia nierozerwalnie związaną z trudem, jaki ponosi artysta.
} 
umieszczał sztukę aktorską w centrum swojego myślenia, ale w przeciwieństwie do Wysockiej stawiał na pełną zespołowość.

Napięcie pomiędzy grą zespołową a aktorską indywidualnością pojawia się w pismach Wysockiej w szczególnym kontekście. Ideałem polskiego teatru pozostaje dla niej zespół Teatru Rozmaitości z okresu epoki gwiazd - czasów, które znała tylko z opowieści lub mogła widzieć w bardzo schyłkowej formie ${ }^{16}$. To, jak go postrzega, podkreślając harmonię i zespołowość połączonych aktorskich indywidualności, daje wyobrażenie o kierunku, w jakim należy dążyć, a ponadto wiąże się z jej własnym stylem gry w zespole. Na scenie nie rezygnowała bowiem ze swojej indywidualności aktorskiej, ale umiała jednocześnie zmotywować innych artystów i wpłynąć na charakter ich scenicznej obecności ${ }^{17}$. Indywidualność aktorska nie oznaczała natomiast eksponowania swojego ja, które z punktu widzenia sztuki było zupełnie nieinteresujące, miarą indywidualności jest raczej talent i styl gry.

Niektóre koncepcje wprowadzane przez Wysocką wiążą się bezpośrednio ze Stanisławskim i jego wciąż wówczas nieskodyfikowaną metodą ${ }^{18}$. Jej echa znaleźć można w takich pojęciach, jak linia postaci czy powiązana z nią linia dramat u, na które składają się motywy działań. Pojęcia prze ży wa nia oraz prawdy nie zostały zdefiniowane w żadnym $\mathrm{z}$ jej pism $\mathrm{z}$ lat dwudziestych, pojawiają się natomiast we wspomnieniach Iwaszkiewicza $z$ Teatru Studya ${ }^{19}$, najprawdopodobniej także za nim przywołuje je Piotr Horbatowski, pisząc o metodzie aktorskiej stosowanej w tym teatrze ${ }^{20}$. Wysocka, zdaniem Iwaszkiewicza, szła w pełni za wskazówkami moskiewskiego mistrza i wpajała je swoim uczniom ${ }^{21}$. Z jej własnej perspektywy sprawa jest bardziej skomplikowana: darzyła Stanisławskiego ogromnym szacunkiem, lecz uważała, że tylko I Studio, oddalające się od naturalizmu, mogło pozytywnie wpłynąć na rozwój sztuki aktorskiej22.

W pismach z pierwszej połowy lat dwudziestych Wysocka stosunkowo niewiele miejsca poświęciła zagadnieniom reżyserii czy scenografii. Reżyser, jej zdaniem, musi się wycofać, pozostawiając pole do popisu aktorom, chociaż jego zdanie i koncepcja pozostają nadrzędne ${ }^{23}$. Powinien być niewidoczną, ale niezbędną siłą, która łączy całe widowisko w spójną całość. Wizyjna scenografia miała dawać pewien obraz miejsca akcji, ale też odsyłać poza konkret. Należało ją ograniczyć,

\footnotetext{
${ }^{16}$ W badaniach nad twórczością Wysockiej ten wątek był dotychczas pomijany, najprawdopodobniej uznawano, że aktorka myli się w ocenie Rozmaitości. Utartą, negatywną opinię o teatrze warszawskim tego okresu zmieniły dopiero wyniki badań Wanickiej, w pewnej mierze pokrywające się z rozpoznaniami Wysockiej. Zob. Agnieszka Wanicka, Dramat i komedia Teatrów Warszawskich 1868-1880 (Kraków: Wydawnictwo Uniwersytetu Jagiellońskiego, 2011), 205-207.

17 Iwaszkiewicz, Wysocka i kijowski teatr "Studya", 32

${ }^{18}$ Echa tych myśli przebijają w tekstach: „Refleksje”i „„Aktor przyszłości”.

19 Iwaszkiewicz, Wysocka i kijowski teatr "Studya”, 22.

20 Horbatowski, Polskie życie teatralne w Kijowie, 182-193.

${ }^{21}$ Iwaszkiewicz, Wysocka i kijowski teatr "Studya", 22-24.

22 Wysocka, Teatr przyszłości, 198-203.

${ }^{23}$ Wysocka, 43-44.
} 
sprowadzić do rzutów architektonicznych lub kotar, aby uniknąć dosłowności ${ }^{24}$. Rekwizyty również były zbędne, ponieważ to aktorzy mieli wypełniać przestrzeń jakością swej obecności. Zarówno reżyser, jak i scenograf w koncepcji Wysockiej pełnią zatem role podrzędne względem aktora, choć reżyser zachowuje pewien rodzaj władzy.

\section{Pedagożka}

Z nieznanych przyczyn Wysocka po przyjeździe do Warszawy nie dołączyła do grona pedagogów reaktywowanej w 1916 Warszawskiej Szkoły Dramatycznej, w której pracowali głównie aktorzy Rozmaitości; być może uważała, że tylko ucząc na własny rachunek, będzie mogła kształtować młodych artystów zgodnie ze swoją koncepcją. Najprawdopodobniej z takiego przekonania narodziło się jesienią 1920 Studio Teatralno-Filmowe przy Wierzbowej 8, które założyła do spółki z fotografem Włodzimierzem Kirchnerem. W szeroko zakrojonym programie szkoły obok zajęć aktorskich znalazły się także umuzykalnienie, rytmika, plastyka ruchu, dykcja, a nawet zajęcia z umiejętności filmowych ${ }^{25}$.

Studio Teatralno-Filmowe funkcjonowało przez jeden sezon, ale po jego rozwiązaniu absolwenci mogli na równi z absolwentami Warszawskiej Szkoły Dramatycznej (która także przestała istnieć) ubiegać się o miejsca na Oddziale Dramatycznym przy Państwowym Konserwatorium Muzycznym. Dyrektorką tej jednostki, później przekształconej w Państwowy Instytut Sztuki Teatralnej, została w 1921 roku Wysocka ${ }^{26}$.

Oddział Dramatyczny bywa marginalizowany w historii dzisiejszej Akademii Teatralnej, podobnie jak postać jego pierwszej dyrektorki. Być może na tej narracji zaważyło przemówienie Jana Kreczmara z 1931, wygłoszone z okazji jubileuszu Aleksandra Zelwerowicza:

Zelwerowicz usunął raz na zawsze ze szkoły swojej chaos w systemie pracy. Ujął pracę tę w żelazne karby wzorowej organizacji, zniósł dowolność studiowania, wprowadził obowiązek terminowego opracowywania zadań, słowem od razu dał odrodzonej w ten sposób uczelni możność poważnej i energicznej pracy. Największą może zasługą Zelwerowicza jako dyrektora Szkoły Dramatycznej jest jednak faktyczne ustalenie programu nauczania, przekształcenie, jeśli tak rzec można, szkółki aktorskiej w akademię teatralną. Zelwerowicz wprowadził więc wymagania cenzusu od nowo wstępujących, oprócz surowego egzaminu wstępnego; wprowadził większą ilość przedmiotów

\footnotetext{
24 Wysocka, 74 .

25 Henryk Szletyński, Siedem gawęd z czasów młodości (Warszawa: Państwowy Instytut Wydawniczy, 1979), 29.

${ }^{26}$ Zbigniew Wilski, Polskie szkolnictwo teatralne 1811-1944 (Wrocław: Zakład Narodowy im. Ossolińskich, 1978), 123.
} 
zarówno teoretycznych, jak i praktycznych, a więc: historię kultury obok historii teatru i dramatu, naukę wymowy oprócz stawiania głosu i solfeggio, gimnastykę, fechtunek, plastykę obok rytmiki ${ }^{27}$.

Kreczmar jednak zaczął naukę w 1926 roku, nie studiował w czasach Wysockiej, która po dwóch latach dyrektorowania przekazała szkołę Zelwerowiczowi, zmuszona do opuszczenia Warszawy z powodu braku stałego angażu. Co więcej, po okresie nauki został zaangażowany do teatru wileńskiego właśnie przez Zelwerowicza. W 1931 Kreczmar bardzo dużo mu zawdzięczał, darzył bez wątpienia ogromnym podziwem i sympatią, a przy tym sformułował tę pochwałę z okazji benefisu, co musiało wpłynąć na jej styl. Szletyński dokonał analizy oraz w pewnym stopniu dyskredytacji tego wspomnienia:

Zelwerowicz nie zastał ani chaosu, ani też braku obowiązujących godzin lub tym podobnych niedostatków. Nie musiał budować, nie musiał organizować. Nie odziedziczył „szkółki aktorskiej”, lecz ukształtowaną szkołę. Doskonaląc istniejący już program i jego realizację, świetnie poprowadził sprawę naprzód o kilka staj. [...] Przedmioty, a przede wszystkim ćwiczenia ruchowe oraz solfeż i impostację, przejął z twórczego ustalenia swojej poprzedniczki. Ale zdynamizował robotę i wciągnął swych wychowanków do rozmaitych zainteresowań, poszerzających horyzonty myśli i obserwacji. Natomiast znacznego osłabienia doznała nauka główna, aktorstwo: ubyła Wysocka (nie mogąc znaleźć pracy w Warszawie, zaangażowała się do Krakowa) i nastąpiło rozstanie z Limanowskim i Osterwą ${ }^{28}$.

Doceniając wysiłek, jaki Zelwerowicz włożył w rozbudowę, a także utrzymanie działalności uczelni, nie można zapominać o tym, że ten sukces był możliwy między innymi dzięki dobrej podstawie, jaką wypracowała Stanisława Wysocka, co mocno podkreśla także Wilski²9.

W momencie otwarcia szkoły w 1921 Wysocka mogła skorzystać z gotowych rozwiązań wypracowanych w Warszawskiej Szkole Dramatycznej, miała jednak własną koncepcję $e^{30}$ Z poprzedniej kadry zatrzymała Zelwerowicza i Osterwę. Wprawdzie mieli inne poglądy na sposoby kształcenia, ale właśnie dzięki obecności trzech tak różnych indywidualności artystycznych tworzyła się atmosfera

\footnotetext{
27 Cyt. za: Szletyński, Siedem gawęd, 36-37.

${ }^{28}$ Szletyński, 37-38. Szletyńskiemu także nie można przypisać bezstronności, szczególnie w cytowanym tomie wspomnień. Czuł się uczniem Wysockiej, a co za tym idzie, występował w obronie jej imienia. Co jednak różni zasadniczo te dwa hołdy złożone mistrzom, to okoliczności i moment spisywania relacjonowanych wydarzeń. Szletyński w latach siedemdziesiątych mógł oceniać rzeczy z dystansu, w przeciwieństwie do Kreczmara piszącego w 1931. Nie był również w żaden sposób związany zawodowo z nieżyjącą już od prawie czterdziestu lat aktorką. Miał szansę na znacznie większą obiektywność, choć nie sposób przemilczeć jego przywiązania do Wysockiej, która wprowadziła go w arkana sztuki aktorskiej.

29 Wilski, Szkolnictwo teatralne, 128.

30 Wilski, 123.
} 
twórczego fermentu, która pozytywnie wpływała na rozwój studentów. Zwolnienie wielkich aktorów poprzedniego pokolenia spotkało się z ostrą krytyką, rozumiano je bowiem jako odrzucenie tradycji. Jednak tylko w ten sposób można było zerwać z dziewiętnastowiecznym sposobem pojmowania ról i kształcić aktorów gotowych do podjęcia wyzwań we współczesnym teatrze.

Artykuł Aktor przyszłości, który Wysocka napisała w 1923, czyli u schyłku swej dyrekcji, daje wyobrażenie o celach edukacji31. Według Wysockiej kształtowanie artysty odbywa się w czterech etapach. Pierwszy stan to śle p o ta, gdy adept może w pełni naśladować swojego mistrza oraz uczyć się swojego ciała, by uczynić je harmonijnym. Wysocka, która sama miała warunki fizyczne raczej utrudniające pracę i rozbieżne ze standardami urody, chciała przekazać swą wiedzę o tworzeniu iluzji optycznych przez odpowiedni ruch, gest czy ułożenie ciała na scenie. Aby przejść do kolejnej fazy, czyli pr zejr ze n ia, trzeba było nauczyć się odpowiednio patrzeć. Ten drugi etap ma bardziej introspekcyjny charakter, ponieważ artysta uczy się patrzeć na siebie z zewnątrz, konstruując drugie ja, które kontroluje jego działania sceniczne. Ta faza zaczyna angażować intelekt konieczny do pracy nad rolą. Trzecim etapem jest in dy widu a li z a cja, przebudzenie duszy oraz emocji. W tym twórczym momencie zaczyna się prawdziwa praca aktorska, która ma doprowadzić do fazy ostatniej, czyli do s y n te zy wszystkich wcześniejszych etapów. Sztuka dramatyczna, tak jak opisywała ją Wysocka, polega przede wszystkim na wcielaniu cudzego ja za pomocą swojego ja, które musi zostać ukryte przed wzrokiem widza.

Warunkiem wypracowania synte zy było opanowanie umiejętności zdobywanych w trakcie edukacji:

Szkoła taka powinna nauczyć ucznia abecadła przyszłej jego działalności. Powinna rozwinąć jego duszę i ciało. Uczeń powinien wyjść ze szkoły z pełną znajomością techniki swej sztuki. Z rozwiniętą wyobraźnią, z umiejętnością skupiania się, z dobrze postawionym głosem, $\mathrm{z}$ umiejętnością używania oddechu, $\mathrm{z}$ wypracowaną wymową. Powinien czuć poezję, rytm i dobrze mówić wiersze. Powinien wyszkolić swoje ciało ${ }^{32}$.

Opracowany przez aktorkę zestaw powinności ucznia, kształtujących zarówno umysł, jak i ciało, miał na celu wypracowanie kompetencji do grania w teatrze przyszłości, który - przypomnijmy - był „rytmem, muzyką i plastyką ${ }^{33}$. Jednocześnie jednak sama Wysocka nadawała edukacji aktorskiej charakter, który dzisiaj określono by jako przemocowy, chociaż w pełni wpisywał się w ówczesne konwencje związane $\mathrm{z}$ wychowaniem. W jej koncepcji aktor podlega tresur ze - zarówno

\footnotetext{
31 Wysocka, Teatr przyszłości, 6o-68

32 Wysocka, 65

33 Wysocka, 55
} 
duchowej, jak i cielesnej34. Wszelka swoboda na pierwszym etapie jest zgubna, lepiej żeby adept naśladował konkretne wzorce i powtarzał wszystko dokładnie za mistrzynią ${ }^{35}$. Dopiero etap trzeci dawał podstawy do samodzielnej pracy. Warto dodać, że styl przypominający pierwszy etap kształcenia Wysocka stosowała na próbach, kiedy jako reżyserka przychodziła z gotową koncepcją niepodlegającą dyskusji.

Edukacja w Oddziale Dramatycznym trwała trzy lata, a nauka odbywała się w godzinach późnopopołudniowych oraz wieczornych. Wysocka wprowadziła szereg przedmiotów: zajęcia z dykcji, impostacji, solfeżu, historii sceny i inscenizacji plastycznej, historii teatru i dramatu, kostiumologii. Rewolucję stanowiły ponadto zajęcia $\mathrm{z}$ rytmiki zamiast tańca salonowego oraz ćwiczenia $\mathrm{z}$ plastyki tańca, gimnastyki, eurytmii i fechtunku ${ }^{36}$. W tym programie widać koncepcję zrównoważonego rozwoju artysty, który powinien zapanować nad swoim ciałem i umysłem, a jednocześnie rozwinąć wiedzę na temat teatru. Nie tylko program był ważny, ale i kadra, która go realizowała. Nauczyciele zatrudniani przez Wysocką byli praktykami, którzy czerpali z najnowszych teorii ${ }^{37}$. Dobór kadry miał gwarantować kształcenie młodych artystów w duchu nowego teatru i definitywnego odejścia od systemu emploi, któremu hołdowano jeszcze w Warszawskiej Szkole Dramatycznej.

Za kadencji Wysockiej po raz pierwszy studentów szkoły aktorskiej dopuszczono do reżyserowania. Na tej podstawie Zelwerowicz stworzył później osobny kurs reżyserii. Koncepcję Wysockiej wyróżniało poczucie, że aktor powinien być kształtowany przez scenę, dlatego adepci niejednokrotnie statystowali w przygotowywanych przez nią sztukach, co prowadziło do konfliktów z zASP-em, który nie chciał dopuszczać na sceny nikogo, kto nie należał do związku. Zmiany wprowadzone przez Wysocką na początku lat dwudziestych wpłynęły na sposób, w jaki nauczanie na wydziałach aktorskich prowadzone jest do dzisiaj.

\section{Dyrektorka}

Działalność pedagogiczną Wysocka łączyła z innymi zajęciami. 12 czerwca 1920 „Kurier Poranny” donosił, że właśnie ona została zaangażowana na stanowisko swojemu koncepcje Rudolfa Steinera. Ponadto: Karol Frycz (kostiumologia), Stanisław Kazuro (solfeż), Halina Hulanicka (plastyka ruchu), Mieczysław Limanowski (psychologia) oraz Wilam Horzyca (historia teatru i dramatu).
} 
głównego reżysera „dramatycznych teatrów miejskich”38. Informacja ta nie została jednak nigdzie powtórzona, nie potwierdza jej także Wilski. Gdyby rzeczywiście chodziło o stanowisko głównego reżysera, sytuacja byłaby bezprecedensowa i można by ją z jednej strony traktować jako wyraz uznania dla dokonań Wysockiej, z drugiej jako emanację ducha czasów, w których kobiety zaczęły realizować się w dziedzinach wcześniej im niedostępnych. Rozważając ten drugi wariant, trzeba jednak pamiętać, że był to wciąż okres wojenny, a więc czas zawieszenia norm związanych z podziałem ról zawodowych na męskie i kobiece. Po wojnie i powrocie mężczyzn $z$ frontu przekraczanie linii tego podziału było znacznie trudniejsze. W czerwcu 1920 Wysocka najprawdopodobniej zastąpiła w zespole Rozmaitości Zelwerowicza, który wyjechał do Łodzi, by objąć tam Teatr Miejski. Jednocześnie w tym samym numerze „Kuriera” zawiadamiano o rozpoczęciu prób do Panny mężatki Józefa Korzeniowskiego. Sprawa jest o tyle intrygująca, że miesiąc później premiera tego dramatu w reżyserii Wysockiej odbyła się w Teatrze w Pomarańczarni i jest uznawana za przedstawienie inauguracyjne zupełnie nowej placówki ${ }^{39}$.

Rozmaitości były wówczas w odbudowie po pożarze, a zespół artystyczny Teatrów Miejskich korzystał z innych scen, które pozostały po dawnych Warszawskich Teatrach Rządowych. Scena w Pomarańczarni tuż po wojnie znalazła się w gestii Zarządu Gmachów Reprezentacyjnych Rzeczpospolitej Polskiej. Ministerstwo Sztuki i Kultury planowało przywrócenie Teatrom Łazienkowskim ich dawnej świetności. Nigdy jednak do tego nie doszło, być może dlatego, że samo ministerstwo bardzo szybko zlikwidowano ${ }^{40}$. Niewykluczone, że planowano przyłączenie Teatru w Pomarańczarni do Teatrów Miejskich, być może na podobnej zasadzie jak Redutę. Według Szczublewskiego Wysocka „dostała Pomarańczarnię do swej dyspozycji”"41. Aktorzy, którzy wystąpili w premierowym spektaklu, a więc Karol Benda, Antoni Różański oraz Helena Sulima, byli etatowymi pracownikami Teatru Rozmaitości, co mogłoby potwierdzać tę wersję. Nie wiadomo niestety nic o finansowaniu tej sceny, a właśnie ta informacja pozwoliłaby rozwiać wątpliwości. Prasa donosiła natomiast o innych planach: Panna mężatka po wakacyjnej

\footnotetext{
${ }^{38}$ Kurier Poranny, nr 158 (1920): 5, https://crispa.uw.edu.pl/object/files/126316/display/Default

39 Informację tę potwierdza lipcowa prasa warszawska, a także Wilski w kalendarium życia artystki, podając, że Wysocka dostała angaż do Teatrów Miejskich dopiero pod koniec sierpnia 1920. Zob. Wilski, Wielka tragiczka, 274

40 Stanisław Marczak-Oborski, Teatr w Polsce 1918-1939: wielkie ośrodki (Warszawa: Państwowy Instytut Wydawniczy, 1984), 15-16.

${ }^{41}$ Zob. Józef Szczublewski, Pierwsza Reduta Osterwy (Warszawa: Państwowy Instytut Wydawniczy, 1965), 65-66. Badacz podkreśla przy okazji, że Wysocka stworzyła teatr po to, aby przeciwstawić się zbyt naturalistycznemu sposobowi gry w Reducie. Opisuje tę sytuację jako rodzaj prywatnej rozgrywki pomiędzy Osterwą a Wysocką: on pierwszy założył teatr, ona ubiegła go, obejmując teatr w Pomarańczarni. Szczublewski specjalnie wyolbrzymia ich rywalizację. Nawet jeśli taka rywalizacja istniała, to oboje za bardzo się szanowali, żeby wejść w otwarty konflikt, o czym może świadczyć kilka epizodów sprzed „sprawy Reduty oraz sprawy Pomarańczarni”. Osterwa, choć go o to proszono w 1917, nie objął opieką zbuntowanych artystów w Teatrze Studya, poradził im, by pogodzili się z dyrektorką. Wysocka zaprosiła Osterwę do nauczania w tworzonym przez siebie Oddziale Dramatycznym przy Konserwatorium. Ich poglądy na teatr oraz konieczność jego odnowy były zbliżone, choć dzieliło ich kilka wspomnianych już wyżej kwestii.
} 
premierze i kilku powtórzeniach $\mathrm{w}$ Łazienkach miała być grana na froncie wojny polsko-bolszewickiej, teatr zaś miałby się stać „lotnym oddziałem propagandy artystycznej" 42 .

Pomarańczarnia nie nadawała się na stały teatr. Budynek był przestarzały, brakowało w nim sanitariatów, znajdował się na obrzeżach miasta, więc do kosztu biletów teatralnych należało doliczyć koszt dojazdu. Wybór tej siedziby miał jednak znaczenie symboliczne. W czasach zaborów Pomarańczarnia funkcjonowała jako prywatny teatr carski. W niepodległej Polsce stała się więc jednym ze znaków odzyskanej wolności. Podczas wojny polsko-bolszewickiej w atmosferze narastającego zagrożenia potrzeba było działań wzmacniających morale. Oddanie teatru w Pomarańczarni publiczności, podobnie jak frontowe pokazy przedstawienia przygotowanego na tej scenie można potraktować jako symboliczny gest tożsamościowy. Przemawia za tym także to, że po wojnie na prawie dziesięć lat zrezygnowano z prób utworzenia tam stałego teatru. Kiedy nie było już wzmożonego zapotrzebowania na działania symboliczne, względy pragmatyczne wzięły górę, a Pomarańczarnia wymagała remontu oraz przystosowania do współczesnych potrzeb.

Tymczasem jednak latem 1920 Wysocka, która od paru lat chciała tworzyć nowoczesny teatr narodowy, właśnie w Pomarańczarni zyskała możliwość realizacji swojej wizji. Spektakl inauguracyjny, Pannę mężatkę Józefa Korzeniowskiego, zaprezentowano 11 lipca 1920. Premiera najprawdopodobniej była powtórzeniem przedstawienia z Teatru Studya. Jak pisze Horbatowski, kijowski spektakl był sukcesem kasowym, w którym połączono wywodzącą się ze Stanisławskiego metodę konstruowania roli z lekkością komedii. Wysocka zdecydowanie przedkładała gest ponad słowo, dlatego mocno skróciła tekst, usuwając między innymi cały pierwszy akt. W Kijowie ton komedii stał się lżejszy, akcja toczyła się w szybszym tempie, na nowo odkryto komizm postaci i sytuacji. Zdaniem Horbatowskiego Wysockiej zależało przede wszystkim na pozbyciu się zbędnej stylizacji historycznej, Korzeniowski miał zabrzmieć współcześnie ${ }^{43}$.

Trudno jednak szukać zrozumienia dla tych zamiarów w warszawskich recenzjach. Sytuacja polityczna nie sprzyjała skupieniu na sztuce, a z relacji recenzentów więcej można się dowiedzieć o nastroju w mieście niż o przebiegu przedstawienia. Z recenzji w „Robotniku”, poza ogólnikami, wynika, że artyści grali bez suflera ${ }^{44}$, co pozwala połączyć ten spektakl z zasadami pracy nad rolą i rozwiązaniami, które Wysocka wypracowała w Kijowie. Jedynie Kornel Makuszyński w „Rzeczpospolitej” szerzej opisał to, co działo się na scenie. Zanotował na przykład, że

\footnotetext{
42 „Teatr w Pomarańczarni", Kurier Poranny, nr 187 (1920): 5, https://crispa.uw.edu.pl/object/files/126288

43 Horbatowski, Polskie życie teatralne w Kijowie, $18 \mathrm{~g}$.

44 B., "Teatr i muzyka", Robotnik, nr 187 (1920): 4, https://polona.pl/item/robotnik-organ-polskiej-partyi-socyalistycznej-26-nr-187-12-lipca-1920,MjE2MzEwMjc/3/\#info:metadata
} 
malowana na płótnie scenografia przedstawiała Kolumnę Zygmunta i „walące się zręby dachów fary" ${ }^{45}$, ale jego zdaniem to sceniczne malowidło nie pasowało do szlachetnego wnętrza Pomarańczarni, „prześlicznej kapliczki sztuki”46. Wydaje się jednak, że scenografia wpisywała się w idee syntetyczności i wizyjności, które głosiła Wysocka. Widz dostawał jasny sygnał, że miejscem akcji jest Warszawa, zamiast mieszczańskiego salonu ujrzał jednak ulicę.

Makuszyński nie ukrywał, że nie ceni sztuki Korzeniowskiego. Chwalił natomiast reżyserskie zabiegi Wysockiej, która według niego „z mistrzowskim trudem” wydobywała komizm z sytuacji nie najlepiej rozwiązanych przez autora. On też jako jedyny - spróbował dokonać szerszego opisu gry aktorskiej, choć trzeba wziąć poprawkę na jego ambiwalentny stosunek do całego przedsięwzięcia. Z jednej strony podkreślał „znakomite do [...] roli przygotowanie” Sulimy wyglądającej na scenie ,jak wspaniały kwiat”, z drugiej - akcentował sztampowość gry Bendy oraz zaledwie sumienność wysiłków Różańskiego, którzy Sulimie partnerowali47. Co ciekawe, nie odniósł się w ogóle do kreacji Wysockiej, jakby jej nie było na scenie i działała jedynie jako reżyserka. Pozostali recenzenci albo pominęli aspekt aktorstwa, albo posłużyli się niewiele dzisiaj mówiącymi ogólnikami w rodzaju: „aktorzy [...] stworzyli postacie pełne życia i prawdy”, a przy tym stanowili „iście koncertowy kwartet"48. Jeśli jednak potraktujemy te sformułowania dosłownie, można połączyć je z koncepcją Wysockiej o konieczności harmonijnego współbrzmienia całego spektaklu oraz o nadawaniu odgrywanym postaciom głębi.

Niespodzianką przedstawienia był... zamach dokonany na teatrzyk przez mechaników amerykańskich, którzy otoczyli gmach automobilami i niby tankami, a po drugim akcie przez usta kierownika wyprawy [...] zapowiedzieli ze sceny, że nie wypuszczą nikogo z teatru, dopóki nie ogołocą wszystkich obecnych z całej gotowizny na rzecz pożyczki państwowej ${ }^{49}$.

Nieznani sprawcy pozostawili widzom po dwie marki na bilet powrotny. O tym szczególnym żarcie wspomina tylko recenzent „Robotnika”, niespodziewanie jednak rzucając światło na widownię - która „składała się przeważnie z literatów i artystów”50. Nie zgadza się to z relacją „Kuriera Warszawskiego”, że jedyną publiczność stanowili zaproszeni notable ${ }^{51}$. Obaj recenzenci widzieli to samo przedstawienie,

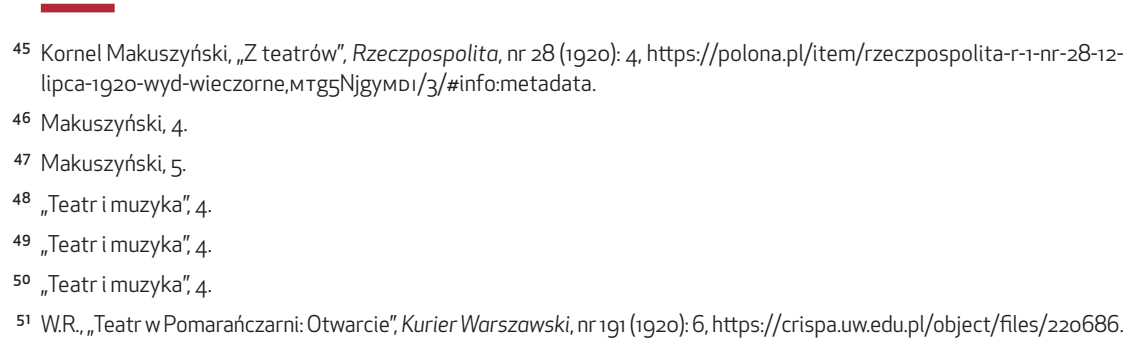


trudno wyjaśnić tak rozbieżne postrzeganie tej samej widowni, można jedynie snuć przypuszczenia powiązane z profilami obu gazet. Sprawozdawca „Robotnika” daje się ponieść nastrojowi wywołanemu przez incydent oraz patriotyczną postawą widowni chętnie oddającej pieniądze, podczas gdy jego kolega $\mathrm{z}$ „Kuriera” poddaje się pesymistycznemu nastrojowi i poczuciu złamania decorum: śmiech powinien zamierać na ustach, kiedy ojczyzna jest w niebezpieczeństwie.

Spektakl zagrano w Pomarańczarni czternastokrotnie, ostatni raz 15 sierpnia w decydującym dla Warszawy dniu słynnej bitwy. Dalsze losy zespołu są niejasne. Może zgodnie z zapowiedziami ruszył na front, a może się rozpadł. W każdym razie zniknął ze szpalt stołecznych gazet. Wiadomo na pewno, że Wysocka pozostała w Warszawie; niecałe dwa tygodnie później na deskach Teatru Letniego wystawiono Lillę Wenedę Słowackiego w jej reżyserii.

Praca w Teatrze w Pomarańczarni to bardzo słabo opisany epizod w biografii Wysockiej, a wydaje się ważny. Artystka miała okazję zaprezentować warszawskiej publiczności swoje dotychczasowe osiągnięcia. Można przypuścić, że wybierając Pannę mężatkę, postawiła na to, co sprawdziło się w Kijowie i nie wymagało dużej obsady ani długich prób. Koncepcja scenograficzna spektaklu oraz metody pracy nad rolami w dość wyraźny sposób łączyły się z poglądami Wysockiej. Można wobec tego traktować Teatr w Pomarańczarni jako swoisty debiut, który miał pokazać warszawianom Wysocką jako reżyserkę przekładającą swoje myślenie o teatrze na sceniczną praktykę.

\section{Teatr Rybałt}

Wysocka kolejne lata poświęciła na poszukiwanie miejsca, w którym mogłaby swobodnie realizować swoje idee odnowy teatru. Irena Schiller przypuszcza, że list, jaki aktorka otrzymała od Stanisławskiego w 1922 roku ${ }^{52}$, mógł stanowić impuls do podjęcia kolejnej próby zorganizowania teatru i szkoły w nawiązaniu do kijowskich doświadczeń. Być może niepowodzenie sceny, którą w 1924 chciała otworzyć w Krakowie ${ }^{53}$, ponownie skierowało jej uwagę w stronę Warszawy. Stworzony tu w 1925 Teatr Rybałt miał podjąć dziedzictwo Studya zarówno poprzez edukowanie młodych artystów od podstaw, jak i poprzez realizację założeń ideowych tamtego teatru. Jednak publiczność nowej sceny mieli stanowić robotnicy.

Można wskazać kilka możliwych źródeł tej idei. Po pierwsze mógł zaważyć na niej kontakt z Witoldem Wandurskim oraz krakowska realizacja Śmierci na gruszy w styczniu 1925 w reżyserii Wysockiej. Zderzyły się tutaj różne wizje teatru, co

\footnotetext{
52 Schiller, Stanisławski a teatr polski, 242-244.

53 Zob. Wilski, Wielka tragiczka, 56 .
} 
położyło się cieniem na współpracy tych dwóch indywidualności. Wysockiej nie interesowała polityczność, nie uważała teatru za narzędzie służące rozbudzaniu mas, a przy tym stroniła od estetyki groteski. Być może z tego powodu często uznaje się, że spektakl w zasadzie wyreżyserował Wandurski, choć firmowała go swoim nazwiskiem Wysocka. Po awanturze, jaką wywołały prawicowe bojówki na premierze, i zdjęciu spektaklu przez cenzurę, Wysocka odcięła się od tej inscenizacji, o czym pisała w liście do Zegadłowicza ${ }^{54}$. Warto jednak spojrzeć na tę premierę jako moment zetknięcia się artystki z ideą teatru dla robotników oraz stylem Wandurskiego, zwłaszcza jego sposobem wykorzystania elementów baśniowych. Drugim - negatywnym - punktem odniesienia jest Teatr im. Bogusławskiego pod wspólną dyrekcją Leona Schillera, Wilama Horzycy oraz Aleksandra Zelwerowicza. Wysocka obserwowała premiery w tym teatrze z pewną niechęcią, ponieważ eksperymenty $\mathrm{z}$ formą prowadzone tam przez Schillera wydawały się jej zimne i nieangażujące ${ }^{55}$.

Nie dziwi wobec tego fakt, że znalazła się wśród osób, które odpowiedziały na ankietę „Życia Teatru” poświęconą zagadnieniu teatru popularnego ${ }^{56}$. Jej opinia na temat stanu polskiego teatru w roku 1925 jest gorzka: „Zawiodły rozmaite dążenia reformatorskie - były one deskami ratunkowymi - które niczego nie uratowały"s7. Aktorka w swojej odpowiedzi zwraca uwagę na kino, widząc w nim narzędzie psucia widowni, ale również najniebezpieczniejszego rywala sztuki scenicznej, którego potencjał można by wykorzystać.

Nawet na twórczości dramatycznej odbija się wpływ kina; powstają sztuki kinowe, których teatr przyjąć nie może, bo nie ma żadnych warunków po temu, chyba, że powstanie nowa forma teatru - połączenie z kinem - coś jak w malarstwie panorama. Tło będzie kinowe, a łączyć się z nim będzie akcja na froncie sceny już z żywych aktorów złożona - tak, aby przejście od kina było przeprowadzone w sposób niewidoczny dla widza. Tu mogłyby powstać wielkie możliwości nowych zdobyczy tak dla twórców dramatycznych, jak i dla aktora, który będzie zmuszony posiąść grę wyrazistą, nie tak jak obecnie ${ }^{58}$.

\footnotetext{
54 Mirosław Wójcik, oprac., Bo Tyjesteś moje Fatum: listy Stanisławy Wysockiej do Emila Zegadłowicza (Kielce: Uniwersytet Humanistyczno-Przyrodniczy Jana Kochanowskiego, 2008), 87.

55 Zob. Wójcik, 131-132, 138.

56 Pytania postawione w ankiecie brzmiały: Jaki repertuar powinien mieć teatr popularny (nie dzielnicowy)? Jaka różnica powinna i czy powinna być między teatrem popularnym a innym? Czy teatr popularny ma być propagatorem nowych form w dramacie i jego inscenizacji? Warto zaznaczyć, że w publicystyce dwudziestolecia międzywojennego, najprawdopodobniej za francuskim terminem, thèâtre populaire, często wymiennie stosowano pojęcia teatr popularny, teatr robotniczy czy teatr ludowy. Teatr im. Bogusławskiego określało się najczęściej jako teatr popularny lub teatr robotniczy, choć sama praktyka sceniczna odstawała od tego, jakim ten teatr chciał widzieć choćby finansujący go magistrat.

57 Wysocka, Teatr przyszłości, 77.

58 Wysocka, 78 .
} 
W centrum uwagi Wysockiej jest więc znów aktor. To brak wyrazistości w grze aktorskiej powoduje, że znudzony widz przestaje słuchać i patrzeć. Przemiany społeczne i kulturowe oraz emocje związane z pierwszą wojną sprawiły, że widzów poruszyć mogą tylko silne bodźce, jakich dostarcza kino. „Śmiech albo płacz [...] silne wrażenia musi dawać teatr duszy dzisiejszego widza, która przeżyła tyle wstrząsów, [...] a do tego potrzeba aktorów - aktorów - aktorów!'”9. Odpowiedź na pytanie postawione $\mathrm{w}$ ankiecie była krótka i logicznie wyprowadzona $\mathrm{z}$ całego wywodu Wysockiej. Repertuar powinien być wartościowy, ale jednocześnie wzbudzać silne emocje: „dobre są melodramaty - tu trzeba rozpocząć walkę z kinem, a właściwie rywalizację"60. Wysocka widziała rozwiązanie problemu w baśniach scenicznych, innych jednak niż u Wandurskiego. Założenie, że „teatr powinien opowiadać piękne, wzniosłe bajki" wykluczało groteskę demaskującą rzeczywistość. Uznawała, że dobry teatr popularny to taki, który nie ma określonego oblicza i raczej porusza serca, niż epatuje formą.

Pierwszym śladem tego, że Wysocka zaczęła przekuwać słowa w działania, jest wywiad, jakiego udzieliła „Kurierowi Poznańskiemu” we wrześniu 1925 na temat tworzonego Teatru Rybałt. Na pytanie, czy organizuje teatr ludowy, odpowiedziała bardzo ostro: „Tylko nie «ludowość»! Dość już ją zdyskredytowano. [...] Otóż w owej «ludowości» jest prawdy tyle, że chcę stworzyć zespół, który będzie grał robotnikom warszawskim”61. Tym razem Wysocka nie szukała siedziby: „Naszym wozem Thespisa będzie tramwaj. Robotnik nie będzie potrzebował szukać teatru. Teatr przyjdzie do niego”. Zaprosiła do współpracy artystów „jeszcze nie nadpsutych", czyli głównie młodzież aktorską po szkole, aby grała, poruszając emocje zupełnie nowego widza, jakim był robotnik. W wywiadzie pojawia się także zapowiedź pierwszej premiery - „Chciałabym otworzyć Balladyna, którą inscenizowałam swego czasu w moich «Studjach» kijowskich jako bajkę" - co $\mathrm{z}$ jednej strony wskazuje na to, że Rybałt miał realizować wizję z ankiety „Życia Teatru”, z drugiej zaś wyraźnie wiąże to nowe przedsięwzięcie z Teatrem Studya.

Trudno ustalić, kiedy zespół zaczął pracę nad tekstem - pierwsze kroki stawiał jeszcze we wrześniu. Jak wynika z korespondencji Wysockiej z Zegadłowiczem, w kolejnych miesiącach próby trwały średnio sześć godzin dziennie ${ }^{62}$. Teatr nie miał żadnego stałego źródła finansowania, do wszystkiego dokładała Wysocka, a młodzi aktorzy zajmowali się również budowaniem i malowaniem scenografii oraz przygotowaniem kostiumów ${ }^{63}$, tak jak w Teatrze Studya. Iwaszkiewicz pisze, że w kijowskim okresie Wysocka miała ogromny szacunek do pracowników

\footnotetext{
59 Wysocka, 82.

60 Wysocka, 82-83.

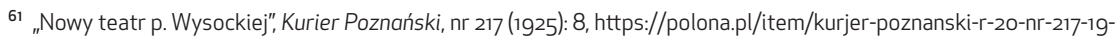
wrzesnia-1925,MTC30DAoMjE/7/\#info:metadatä Kolejne cytaty w akapicie pochodzą z tego samego źródła.

62 Wójcik, Bo Tyjesteś moje Fatum, 135

63 Wójcik, 139.
} 
technicznych teatru ${ }^{64}$. Może zlecanie różnych prac młodym wynikało nie tylko z kłopotów finansowych, lecz miało im także uzmysłowić, jak wiele wysiłku pozascenicznego potrzeba, aby doszło do przedstawienia.

Premierowy pokaz Balladyny odbył się 20 grudnia 1925 w siedzibie Towarzystwa Pracowników Handlowych przy ulicy Siennej 16 w Warszawie. Samo wydarzenie poprzedziła prelekcja Wysockiej na temat założeń ideowych Rybałta, co odbiło się w recenzjach doceniających widowisko przede wszystkim ze względu na jego społeczny aspekt ${ }^{65}$. Dość zgodnie chwalono scenografię Tadeusza Gronowskiego "łączącą ekonomię środków artystycznych [...] z ich celowością" ${ }^{66}$. Z tego opisu oraz relacji Irzykowskiego ${ }^{67}$ wiadomo, że scenografia była skrótowa, raczej malowana i płaska - bardziej symbolizowała miejsce, niż nim rzeczywiście była. Wpisywała się zatem w poglądy Wysockiej na temat plastycznej oprawy przedstawień.

Prasowe zapowiedzi o „oryginalnym opracowaniu inscenizacyjnym S. Wysockiej”68, skłaniają do przypuszczenia, że wykorzystała kijowski scenariusz. Sugeruje to także wrażenie Iwaszkiewicza: „każde słowo pamiętane, każdy gest i każdy obraz przysłaniały mi wspomnienia" ${ }^{69}$. Tym razem jednak, inaczej niż w Kijowie, na scenie nie było Wysockiej. Nie wystąpiła, „nie chcąc zapewne zezwolić na dysonans, jaki by się w tych warunkach musiał niewątpliwie wytworzyć"7o. O kształcie całego widowiska tak pisał Irzykowski:

Najcharakterystyczniejsza była scena, kiedy Kirkor przychodzi do chaty wdowy. Cztery osoby, a oprócz tego Skierka, poruszają się jakby tylko w jednej płaszczyźnie. Kirkor przychodzi i od razu zwraca się twarzą do publiczności i deklamuje swoje, prawie nie patrząc na obie dziewice, choć niby w obu się zakochał i obie w pięknych słowach opisuje. Wszyscy stoją i rozmawiają. Alina i Balladyna podniosły ręce od łokcia do góry [...] i tak trwają. [...] Wysocka w zapale antyrealistycznym [...] każe swoim postaciom trwać tak przed przekrojem chaty, w jednej płaszczyźnie, prawie w niezmiennej pozycji i choć Wdowa zaprasza rycerza [...], jednak ruchów odpowiednich wcale nie widać ${ }^{11}$.

\footnotetext{
64 Iwaszkiewicz, Wysocka i kijowski teatr "Studya”, 68.

65 Jarosław Iwaszkiewicz, „Ruch teatralny”, Wiadomości Literackie, nr 1 (1926): 5, http://mbc.malopolska.pl/dlibra doccontent?id=57855 E.S., "Inauguracja «Rybałta», Echo Warszawskie, nr 342 (1925): 4, https://polona.pl/item/echowarszawskie-bezpartyiny-dziennik-ilustrowany-r-2-nr-342-22-grudnia-1925,0DcyNTgwMzE/3/\#info:metadata

66 „Inauguracja «Rybałta»", 4.

67 Karol Irzykowski, ,Sprawozdanie teatralne", Robotnik, nr 352 (1925): 2-3, https://polona.pl/item/robotnik-organ-polskiej partyi-socyalistycznej-r-31-nr-352-23-grudnia-1925,MjE2NDk2MDM/1/\#info:search

68 Iwaszkiewicz, Wysocka i kijowski teatr "Studya", 68.

69 Iwaszkiewicz, "Ruch teatralny", 5 .

70 St.P., Teatr «Rybałt»", Polska Zbrojna, nr 351 (1925): 7, https://polona.pl/item/polska-zbrojna-pismo-codzienne-r-5 rr-351-22-grudnia-1925,MjE10DQZMTM/6/\#item

71 Irzykowski, „Sprawozdanie teatralne", 2.
} 
Wysocka liczyła zapewne, że pięknie deklamowane słowa dramatu porwą słuchaczy. Wiele wskazuje jednak na to, że w tym wypadku przeważyła forma, choć przecież aktorka odnosiła się do niej z dystansem. Jak sugeruje recenzent „Echa Warszawskiego", w przedstawieniu pojawiły się typowe dla reżyserii Wysockiej chwyty: "przerost formy, gestu i monotonii słowa" ${ }^{2}$. Nie odrzucano jednak całkowicie koncepcji, problem dostrzegano raczej w niedoświadczeniu aktorów i nierówności ich gry ${ }^{73}$. „Dobry popis szkoły deklamacji” - tak skwitował całość Irzykowski ${ }^{74}$. W recenzjach uderza szczególny ton: szlachetnemu przedsięwzięciu udzielano kredytu zaufania. A może przedstawienie dla klas niższych oraz prowincjonalnej widowni nie musiało spełniać tych samych standardów, co inscenizacje w stałych teatrach?

Zespół występował początkowo na Ochocie, później na Woli, czyli w gęsto zaludnionych i coraz prężniej rozwijających się dzielnicach miasta. W styczniu, dzięki protekcji ze strony kuratorium, Rybałt zaczął otrzymywać zaproszenia ze szkół75. Wysocka źle się jednak czuła w Warszawie i marzyła o objeździe, który pozwoliłoby zaprezentować efekty pracy szerszej publiczności. Pozyskanie pieniędzy na ten cel wiązało się ze żmudną wędrówką po urzędach i przekonywaniem ministrów i dyrektorów, aby z budżetów swoich instytucji wsparli teatr. Głównym dobroczyńcą zespołu został Jan Skotnicki, dyrektor Departamentu Kultury i Sztuki w Ministerstwie Wyznań Religijnych i Oświecenia Publicznego ${ }^{76}$. Wysockiej udało się także namówić Władysława Raczkiewicza, wówczas ministra spraw wewnętrznych, aby podarował Rybałtowi tysiąc pięćset złotych ${ }^{77}$. Jak donosiła $\mathrm{w}$ jednym $\mathrm{z}$ listów:

moje awantury w Min[isterstwie] Kolei odniosły dobry skutek - dali najwyższe zniżki i 2 wagony, w jednym będziemy mieszkać, a drugi na dekoracje i rzeczy. Wyrobiłam sobie szerokie znajomości we wszystkich minist[erstwach ${ }^{78}$.

Dzięki temu udało się zorganizować objazd, który trwał od 27 lutego do końca marca 1926 i swoim zasięgiem objął południowo-wschodnią część Polski79. Obok Balladyny, w której Wysocka kilkukrotnie wystąpiła w tytułowej roli, zespół grał także Starego kawalera Józefa Korzeniowskiego.

\footnotetext{
72 „Inauguracja «Rybałta»", 4 .

73 „Inauguracja «Rybałta»", 4 .

74 Irzykowski, "Sprawozdanie teatralne”, 2.

75 Wójcik, Bo Ty jesteś moje Fatum, 145

76 Wójcik, 145 .

77 Wójcik, 150.

78 Wójcik, 150

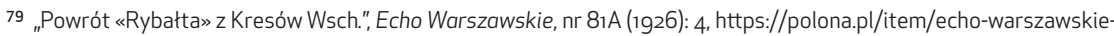
bezpartyjny-dziennik-ilustrowany-r-3-nr-81a-8-kwietnia-1926,oDcynTgxNTA/3/\#info:metadata
} 
Zdaje mi się, że robimy duży czyn kulturalny - bo dajemy dużo przedstawień dla szkół i wojska - pierwszy to raz młodzież na Kresach dostaje coś dla siebie. Przedstawienia tu bywają tak natłoczone, że ledwie budynek teatralny wytrzymuje. Ot, wczoraj było 1000 osób ze szkół - kilka szkół żydowskich - a że Żydzi tutaj są przeważnie kultury rosyjskiej, więc dla polskości młodego pokolenia to jest b[ardzo] ważne. [...] W każdym bądź razie i tak jestem zadowolona, bo daliśmy się poznać. Balladyna odnosi wszędzie sukces [...]. Stary kawaler też się podoba - idzie dobrze ${ }^{80}$.

Doświadczenie docierania do grup zazwyczaj wykluczonych z głównego obiegu kulturalnego było dla Wysockiej niezwykle ważne. Osobnym wątkiem wymagającym namysłu jest kwestia politycznego wymiaru tego przedsięwzięcia: finansowanie objazdu częściowo ze środków ministerialnych wiązało się w jakiejś mierze z polityką narodowościową II RP.

Sukcesy frekwencyjne były tylko jedną stroną medalu. Z listów do Zegadłowicza wiadomo, że nieznany z nazwiska impresario pobierał wysoki procent od zarobków trupy ${ }^{\mathbf{8 1}}$. Chociaż dochody wystarczyły jedynie na pokrycie dziennych gaż artystów oraz najbardziej pilnych potrzeb, dyrektorka snuła fantazje na temat kolejnych wypraw: objazdu po kraju z Hamletem Shakespeare’a połączonym z jakąś polską komedią, a nawet wojaży zagranicznych ${ }^{82}$. Ostatecznie planom, choćby krótkiego wyjazdu na Pomorze, przeszkodziła sytuacja polityczna i gospodarcza kraju - niedofinansowane ministerstwa wycofywały obietnice subwencji ${ }^{83}$.

Niestabilna sytuacja polityczna w kraju niedługo później przerodziła się w krwawy przewrót majowy. Wysocką bardzo poruszyły te wydarzenia, a jej teatr 25 maja wystawił Nadzieję Hermana Heijermansa, sztukę z żelaznego repertuaru teatrów robotniczych ${ }^{\mathbf{4}}$. Po tej premierze Rybałt właściwie zniknął ze szpalt stołecznych gazet. Jedynie z listów Wysockiej wynika, że zespół nadal grał dla robotników w siedzibach ich związków ${ }^{85}$. Jak podaje Wilski, ostatnie przedstawienie Rybałt dał 27 czerwca $1926^{86}$. Upadek teatru został odnotowany w satyrycznym numerze

\footnotetext{
80 Wójcik, Bo Ty jesteś moje Fatum, 156-157.

81 "Mamy kłopot tylko z naszym impresariem - okrada, zdaje się, niemiłosiernie [...] ale, co robić, bez niego nie udałoby się zrobić tego objazdu", Wójcik, 154

82 Wójcik, 157.

83 Wójcik, 164.

84 To ciekawy moment w biografii Wysockiej: w liście do Zegadłowicza widać radykalizację jej poglądów politycznych i zwrot na lewo: ,już teraz jestem zupełnie czerwona - z tamtym światem skończyłam - nie cierpię burżujów - nie znoszę panów od wyścigów - którzy w hotelu chowają swoją cenną skórkę - gdy krew się leje", Wójcik, 178.

85 Wójcik, 178.

86 Wilski, Wielka tragiczka, 277. Tymczasem w Kurierze Czerwonym z 26 czerwca 1926 pojawia się informacja, że „dziś, jutro i w poniedziałek trzy gościnne występy teatru «Rybałt» w dramacie Nadzieja" w teatrze Odrodzonym. „Repertuar", Kurier Czerwony, nr 144 (1926): 3, https://crispa.uw.edu.pl/object/files/617497
} 
„Wiadomości Literackich” czyli „Jadąmośkach Literackich” z lipca $1926^{87}$, gdzie nad godłem czasopisma, w miejscu standardowej informacji o „opłacie uiszczanej ryczałtem” pojawił się tekst „Wysocka kresowa wyniszczona rybałtem”. Rybałt podzielił los wielu innych warszawskich scen, które przegrały walkę o finansową stabilizację. Pomimo starań i nadziei teatr, podobnie jak wcześniejsze inicjatywy Wysockiej, nie był w stanie utrzymać się wystarczająco długo, by doprowadzić do zmiany. Ostatnie takty tej historii to podjęta wspólnie z Ireną Solską oraz Jerzym Hulewiczem inicjatywa przejęcia budynku po Teatrze im. Bogusławskiego ${ }^{88}$, ostatecznie zakończona fiaskiem.

Rybałt wydaje się najpełniejszą i najbliższą realizacji próbą odtworzenia Teatru Studya w niepodległej Polsce. Brakuje jednak dokumentów, które pozwoliłyby na pełne opisanie sytuacji w zespole, przyjętych metod pracy czy panującej w nim atmosfery. Nie wiadomo, w jakim stopniu Wysocka stosowała metody pedagogiczne wypracowane kilka lat wcześniej w Kijowie, a rozwijane później w Oddziale Dramatycznym. Nie wiadomo także, czy teksty, wybrane zgodnie z tezą, że w teatrze dla robotników potrzebna jest baśniowość, rzeczywiście odpowiadały publiczności; nikt nie przeprowadził wśród niej badań na ten temat.

\section{Niepowodzenia?}

Warszawa lat dwudziestych nie była ulubionym miastem Wysockiej, mimo że uparcie do niego wracała. Ambiwalentne relacje łączyły artystkę także z krytykami i publicznością. Chłodne przyjęcie Panny mężatki i kolejne niepowodzenia reżyserskie na scenach Teatrów Miejskich mogły zaważyć na tym, jak postrzegano Wysocką. Aktorka, której wybitny talent podkreślano na każdym kroku, nie mogła znaleźć sobie na dłużej miejsca w żadnym z warszawskich teatrów. Sytuacja zmieniła się na początku lat trzydziestych, kiedy przestała organizować grupy teatralne, naciskać na reformę teatru oraz zmieniła emploi. Gdy zaczęła częściej grać starsze kobiety, zazwyczaj pozbawione realnej władzy, a przy tym nierzadko ujmowane komicznie, zaczęto ją doceniać i lubić. Niewykluczone, że nowe emploi zmieniło publiczny wizerunek Wysockiej. Opinie na jej temat można powiązać z postawą, którą prezentowała w latach dwudziestych, gdy głośno wyrażała swoje sądy, nie dawała się łatwo uciszyć i formułowała wyraziste deklaracje etyczne i estetyczne. Warszawa, w której do połowy lat trzydziestych wybory wygrywała konserwatywna endencja, raczej nie była miejscem sprzyjającym silnym kobietom ${ }^{89}$. Podobnie jak

\footnotetext{
87 Jadąmośki Literackie: Tygojnik, lipiec 1926 (numer specjalny Wiadomości Literackich): 1.

88 [Adam Zagórski], „Zabawa w kręćka", Przegląd wieczorny, nr 171 (1926):3, https://crispa.uw.edu.pl/object/files/148922

89 Zob. Marian Marek Drozdowski, Warszawiacy i ich miasto w latach Drugiej Rzeczypospolitej (Warszawa: Wiedza Powszechna, 1973), 300-344
} 
inne aktorki, które chciały realizować swoje założenia, Wysocka natrafiała na mur trudności i obojętności. Poza Janiną Korolewicz-Waydową oraz Marią Strońską żadna $\mathrm{z}$ aktorek nie została $\mathrm{w}$ tym okresie dyrektorką istniejącej już instytucji, choć artystki same tworzyły teatry, w których mogłyby realizować swoje wizje. Większość z nich także, jak Stanisława Wysocka, musiała na każdym kroku walczyć o subwencje oraz przetrwanie prowadzonych zespołów.

Warto jednak podkreślić, że pozycja zawodowa Wysockiej, szacunek środowiska oraz jej aktorskie i reżyserskie dokonania sprawiały, że miała szansę trafić tam, gdzie żadnej innej kobiecie się nie udało - choćby realizować swoje projekty na scenach największych stołecznych teatrów. Wysocka pozostaje jedyną reżyserką, która w dwudziestoleciu reżyserowała zarówno na scenie Teatru Narodowego, jak i na scenach koncernu Arnolda Szyfmana.

Stanisława Wysocka w latach dwudziestych próbowała kontynuować misję reformowania teatru rozpoczętą w Kijowie. Walczyła piórem - bezpardonowo atakując lenistwo myślowe, wyczerpaną estetykę naturalizmu oraz porządki panujące we współczesnym teatrze. Podejmowała energiczne działania, aby swoje idee urzeczywistnić, czego manifestacją były krótkie żywoty Teatru w Pomarańczarni oraz Teatru Rybałt. Przede wszystkim jednak miała świadomość, że trzeba wszechstronnie kształcić młodych artystów, by zerwać z dziewiętnastowiecznym sposobem gry aktorskiej, dlatego podjęła pracę pedagogiczną, którą prowadziła przez całe dwudziestolecie. $Z$ analizy jej życiorysu oraz scenicznych dokonań wynika, że jej pisma teoretyczne były powiązane z praktyką i niejednokrotnie bezpośrednio z niej wyrastały. Nie miała jednak kontynuatorów powołujących się otwarcie na jej dziedzictwo, dlatego próba określenia jej wpływu na polski teatr wciąż wymaga szerszych badań porównawczych. Stanisława Wysocka ma miejsce w historii jako wybitna aktorka, jednak jej ambicje oraz wielotorowe próby odnowy sztuki scenicznej sprawiają, że należałoby umieścić ją także w gronie reformatorów polskiego teatru.

\section{Bibliografia}

Drozdowski, Marian Marek. Warszawiacy i ich miasto w latach Drugiej Rzeczypospolitej. Warszawa: Wiedza Powszechna, 1973.

Horbatowski, Piotr. Polskie życie teatralne w Kijowie 1905-1918. Kraków: Wydawnictwo Uniwersytetu Jagiellońskiego, 2009.

Iwaszkiewicz, Jarosław. Stanisława Wysocka i jej kijowski teatr „Studya”: wspomnienie.

Warszawa: Wydawnictwa Artystyczne i Filmowe, 1963.

Marczak-Oborski, Stanisław. Teatr w Polsce 1918-1939: wielkie ośrodki. Warszawa: Państwowy Instytut Wydawniczy, 1984.

Schiller, Irena. Stanisławski a teatr polski. Warszawa: Państwowy Instytut Wydawniczy, 1965. 
Sokolicz, Antonina. „Reformatorzy teatru”. W: Myśl teatralna polskiej awangardy 1918-1939: antologia, wybór i wstęp Stanisław Marczak-Oborski, 301-304. Warszawa: Wydawnictwa Artystyczne i Filmowe, 1973.

Szczublewski, Józef. Pierwsza Reduta Osterwy. Warszawa: Państwowy Instytut Wydawniczy, 1965.

Szletyński, Henryk. Siedem gawęd z czasów młodości. Warszawa: Państwowy Instytut Wydawniczy, 1979.

Wanicka, Agnieszka. Dramat i komedia Teatrów Warszawskich 1868-1880. Kraków: Wydawnictwo Uniwersytetu Jagiellońskiego, 2011.

Wilski, Zbigniew. Polskie szkolnictwo teatralne 1811-1944. Wrocław: Zakład Narodowy im. Ossolińskich, 1978.

Wilski, Zbigniew. Wielka tragiczka. Kraków: Wydawnictwo Literackie, 1982.

Wójcik, Mirosław, oprac. Bo Ty jesteś moje Fatum: listy Stanisławy Wysockiej do Emila Zegadłowicza. Kielce: Uniwersytet Humanistyczno-Przyrodniczy Jana Kochanowskiego, 2008.

Wysocka, Stanisława. Teatr przyszłości. Warszawa: Wydawnictwa Artystyczne i Filmowe, 1973.

\section{Abstrakt}

\section{Warszawskie teatry Stanisławy Wysockiej}

Artykuł prezentuje wybrane aspekty działalności reżyserskiej i pedagogicznej Stanisławy Wysockiej w dwudziestoleciu międzywojennym. Autorka szuka powiązań między teorią a praktyką Wysockiej, zestawiając postulaty z jej tekstów publicystycznych o „teatrze przyszłości” z przedsięwzięciami pedagogicznymi i teatralnymi podjętymi w latach 1920-1926. Zarówno inicjatywy edukacyjne, jak i próby stworzenia własnych scen w Warszawie (Teatr w Pomarańczarni i Teatr Rybałt) zostały pokazane jako kontynuacja idei kijowskiego Teatru Studya. W wizerunku Wysockiej jako pedagożki, reżyserki i dyrektorki zaakcentowano te cechy jej myślenia o teatrze, które mają reformatorski charakter: nowoczesne i holistyczne podejście do procesu kształcenia artystów, świadomość współzależności artystycznych i organizacyjno-technicznych aspektów działalności teatralnej, otwarcie na potrzeby nowej, demokratyzującej się widowni.

\section{Słowa kluczowe}

Stanisława Wysocka, teatr polski 1918-1939, Teatr Rybałt, Teatr w Pomarańczarni, Oddział Dramatyczny przy Państwowym Konserwatorium Muzycznym, sztuka aktorska, reforma teatru

\section{Abstract}

\section{The Warsaw Theaters of Stanisława Wysocka}

This article presents selected aspects of Stanisława Wysocka's directing and teaching activity in the interwar period. The author seeks out links between Wysocka's theory and practice, discussing postulates from her journalistic texts about the "theater of the future" alongside her pedagogical and theatrical projects from 1920-1926. Both Wysocka's 
educational initiatives and attempts at establishing her own theaters in Warsaw (Teatr w Pomarańczarni [Orangery Theater] and Teatr Rybałt) are approached as a continuation of the ideas of Teatr Studya in Kyiv. In Wysocka's image as an educator, director and manager, the author emphasizes reformatory ideas about the theater: her modern and holistic approach to the process of artist training, her awareness of the interdependence of artistic and organisational/technical aspects of running a theater, and her openness to the needs of the new, "democratizing" audience.

\section{Keywords}

Stanisława Wysocka, Polish theater 1918-1939, Teatr Rybałt, Teatr w Pomarańczarni, Department of Drama at the State Conservatory of Music, art of acting, theater reform

\section{BARBARA MICHALCZYK}

doktorantka w Katedrze Teatru i Dramatu Wydziału Polonistyki Uniwersytetu Jagiellońskiego. Absolwentka Wydziału Wiedzy o Teatrze Akademii Teatralnej im. Aleksandra Zelwerowicza w Warszawie. W swoich zainteresowaniach badawczych skupia się przede wszystkim na dziejach teatru w dwudziestoleciu międzywojennym oraz perspektywie feministycznej w badaniach nad historią teatru. 